\title{
Endothelial Dysfunction and Essential Hypertension
}

\author{
1 Jay Khambhati, ${ }^{2}$ Suegene K Lee, ${ }^{3}$ Bryan Kindya, ${ }^{4}$ Devinder Dhindsa, ${ }^{5}$ Pratik B Sandesara, ${ }^{6}$ Arshed A Quyyumi
}

\begin{abstract}
Systemic hypertension is a chronic disorder of cardiovascular system characterized by an increase in systemic vascular resistance (SVR). Although the level of blood pressure is a product of SVR and cardiac output, it is the former which is responsible for chronic blood pressure elevation. A number of biochemical, biophysical, and neuro-humoral factors participate in the maintenance of SVR. Whatever the underlying molecular mechanism may be for elevated SVR, the end consequence is endothelial dysfunction. Normal endothelium promotes vasodilation and prevention of local thrombotic phenomena whereas abnormal endothelium promotes vasoconstriction and thrombotic processes. One of the basic pathophysiological aberrations in hypertension is abnormal endothelial function. A number of blood pressure lowering strategies (life-style modification and or anti-hypertensive drugs) result in reversing endothelial dysfunction in hypertension. Thus, endothelial function is considered both as a mechanism and a therapeutic target in hypertension. This review summarizes the physiology and pathophysiology of endothelium in hypertension.
\end{abstract}

Keywords: Aminothiols, Cardiovascular, Dimethylarginine, Hypertension.

How to cite this article: Khambhati J, Lee SK, Kindya B, Dhindsa D, Sandesara PB, Quyyumi AA. Endothelial Dysfunction and Essential Hypertension. Hypertens J 2017;3(2):81-88.

Source of support: AAQ is supported by the National Institutes of Health (NIH) grants 5P01HL101398-02, 1P20HL113451-01, 1R56HL126558-01, 1RF1AG051633-01, R01 NS06416201, R01 HL89650-01, HL095479-01, 1U10HL110302-01, 1DP3DK094346-01, 2P01HL086773-06A1.

Conflict of interest: None

\section{INTRODUCTION}

Endothelial cells form the innermost monolayer of the vascular wall in arteries, veins, and capillaries. The endothelium functions both as an endocrine organ, expressing receptors for cellular and hormonal communication, and as a paracrine organ, producing vasoactive, inflammatory, vasculoprotective, angiogenic, thrombotic,

\footnotetext{
${ }^{1-6}$ Consultant

${ }^{1-6}$ Division of Cardiology, Department of Medicine, Emory Clinical Cardiovascular Research Institute, Emory University School of Medicine, Atlanta, Georgia, USA

Corresponding Author: Suegene Lee, Consultant, Division of Cardiology, Department of Medicine, Emory Clinical Cardiovascular Research Institute, Emory University School of Medicine, Atlanta, Georgia, US, e-mail: suegene.lee@emory. edu
}

and antithrombotic molecules. ${ }^{1,2}$ It exists in persistent homeostasis, balancing blood fluidity and thrombosis, vascular inflammation and immunologic processes, and importantly, regulating vascular tone. We will focus on endothelial regulation of vascular tone in hypertension in this review.

Vascular tone is critically regulated by the endothelium via the synthesis and release of a variety of endotheliumderived factors that exist in a delicate balance with each other. Endothelin-1 (ET-1), angiotensin II, thromboxane $\mathrm{A} 2$, and reactive oxygen species mediate vasoconstriction, whereas nitric oxide (NO), prostacyclin, carbon monoxide, and other endothelium-derived hyperpolarizing factors mediate vasodilation. ${ }^{3,4}$ Among these, $\mathrm{NO}$ appears to be a critical regulator of vascular homeostasis. ${ }^{5}$

\section{PATHOPHYSIOLOGY OF ENDOTHELIAL DYSFUNCTION AND HYPERTENSION}

Endothelial dysfunction (ED) occurs early after the diagnosis of essential hypertension and may even precede it. ${ }^{6}$ A major characteristic of ED is decreased NO bioavailability. Endothelial cells synthesize NO through the constitutive expression of nitric oxide synthase-3 (NOS-3), also known as endothelial nitric oxide synthase (eNOS), ${ }^{6}$ which facilitates both coupled and uncoupled reactions. In the healthy endothelium, a coupled eNOS leads to a $\mathrm{Ca}^{2}+$ /calmodulin (CaM)-dependent phosphorylation that converts $\mathrm{L}$-arginine to $\mathrm{L}$-citrulline, resulting in generation of NO. ${ }^{1}$ The release of NO leads to smooth muscle vasodilation via a cyclic guanylate monophosphate (cGMP)-mediated activation of guanylate cyclase, altering resting vasomotor tone.

In conditions of increased oxidative stress (OS), an uncoupled $\mathrm{Ca}^{2}+/ \mathrm{CaM}$-independent reaction generates superoxide anions rather than NO. ${ }^{1}$ In this state, Larginine and tetrahydrobiopterin (BH4) are depleted and peroxynitrite and asymmetric dimethylarginine (ADMA) levels are increased. Excess superoxide typically leads to further depletion of $\mathrm{NO}$ by formation of peroxynitrite, destabilization of eNOS, and an overall reduction in NO bioavailability. Overall, a reduction in substrate (L-arginine) levels, presence of eNOS antagonists, elevated breakdown of NO due to OS, and decreased cofactors for eNOS, such as tetrahydrobiopterin lead to decreased NO bioavailability. ${ }^{2}$ Decreased NO availability leads to excess vasomotor tone, which in turn leads to hypertension, spasm, triggers of ischemic events, and other deleterious 
effects on vasculature. Depletion of $\mathrm{NO}$ also results in nuclear factor-kappa $\beta$ (NF- $\mathrm{B}$ )-dependent activation of adhesion molecules, such as selectins that promote vascular inflammation and increase the thrombotic potential of platelets and blood coagulability, ultimately increasing the risk of atherosclerosis and thrombosis. ${ }^{7}$ Inflammation and $O S$ are associated with traditional and nontraditional cardiovascular risk factors, including essential hypertension. $^{2}$ Furthermore, reduced NO is associated with decreased endothelial progenitor cell (EPC) activity and function, thus impairing vascular regenerative potential. ${ }^{8}$ Thus, decreased NO bioavailability leads to an alteration in endothelial homeostasis, creating a vasoconstrictive, proinflammatory, proatherosclerotic, prothrombotic, and antiregenerative milieu. ${ }^{1}$

\section{INVASIVE EVALUATION OF ENDOTHELIAL FUNCTION}

Endothelial function can be estimated with both invasive testing of the coronary or peripheral vasculature and by noninvasive techniques. Assessment of coronary endothelial function is performed by direct infusion of endothelium-dependent vasodilators, such as acetylcholine, bradykinin, substance $\mathrm{P}$, and others followed by measurement of changes in epicardial diameter and coronary blood flow. In the setting of normal endothelial function, acetylcholine causes epicardial dilation and increase in coronary blood flow. With ED, epicardial arteries constrict and flow increases to a lesser extent than in the normal setting. $1,9,10$

Measurements of blood flow changes during intrabrachial arterial infusion of these endothelium-dependent vasodilators can be used to assess endothelial function in the forearm circulation. ${ }^{4}$ During forearm plethysmography, venous drainage is briefly interrupted by inflating a blood pressure cuff, while arterial inflow is maintained. Flow measurements are recorded as endothelial vasodilators are infused. In the setting on normal endothelial function, acetylcholine, a commonly used endotheliumdependent agonist, stimulates release of NO and other endothelium-dependent vasodilators, resulting in vasodilation of the forearm circulation. ${ }^{11}$ To study the contribution of NO to the observed vasodilation, inhibitors of NO and other endothelium-derived relaxing factors can be employed. ${ }^{11-20}$ Finally, to study endothelium-independent function, NO donors, such as nitroprusside or nitroglycerine are given and blood flow responses measured.

\section{NONINVASIVE EVALUATION OF ENDOTHELIAL FUNCTION}

Flow-mediated dilation (FMD) uses high-resolution ultrasound to assess endothelium-dependent brachial reactivity. The FMD of the brachial artery is almost entirely due to shear-mediated release of NO from the intact brachial artery endothelium and correlates with coronary artery endothelium-dependent responses to acetylcholine, effectively serving as a surrogate marker for coronary endothelial function. ${ }^{21}$ After transiently inducing ischemia by cuff inflation for 5 minutes and subsequent deflation, the resulting hyperemia increases brachial artery shear stress that releases NO from the healthy endothelium and causes the brachial artery to dilate. The magnitude of this FMD is proportional to the NO release from the endothelium. ${ }^{6}$

\section{ENDOTHELIAL FUNCTION AND ADVERSE CARDIOVASCULAR OUTCOMES}

Endothelial dysfunction, regardless of the underlying cause, is an independent predictor of future adverse cardiovascular events. ${ }^{22-24}$ In 3,026 subjects free of cardiovascular disease from the Multi-Ethnic Study of Atherosclerosis (MESA), followed for 5 years, each SD increase in FMD conferred a hazard ratio of 0.84 for incident cardiovascular events. Importantly, FMD also improved net reclassification of risk when compared with the Framingham risk score. ${ }^{24}$ Two further studies in more selected populations, including the Cardiovascular Health Study of elderly subjects and a study by Rossi et $\mathrm{al}^{25}$ in over 2,000 postmenopausal women, support these findings by demonstrating significant association between impaired FMD and cardiovascular outcomes. ${ }^{24-26}$

\section{ENDOTHELIAL DYSFUNCTION IN HYPERTENSION}

A traditional and widely accepted viewpoint is that hypertension is a cause rather than a consequence of ED. Acute and chronic hypertension precipitates ED. ${ }^{27,28}$ The Cardiovascular Risk in Young Finns study found that abnormal blood pressure in youth tended to predict future impaired endothelial function. ${ }^{4}$ In a cross-sectional analysis of 3,500 middle-aged participants in MESA, hypertension was associated with a lower FMD in all ethnicities. $^{29}$ Finally, the degree of ED is related to the magnitude of blood pressure elevation. ${ }^{30,31}$

Multiple mechanistic studies have shown that the ED observed in hypertension is associated with reduced NO bioavailability in both conductance vessels and the microvasculature. ${ }^{32}$ Acetylcholine-mediated coronary and forearm vasodilation is blunted in hypertension compared with normotensive controls. ${ }^{11}$ However, a study in a younger hypertensive population did not confirm this finding. ${ }^{33}$ To determine whether the reduced vasodilation with acetylcholine is due to reduced NO bioavailability, acetylcholine infusion was repeated after administration 
of $\mathrm{N}^{\mathrm{G}}$-monomethyl-L-arginine, a competitive inhibitor of eNOS synthesis. Inhibition of acetylcholine response was greater in normotensive than in hypertensive subjects, indicating reduced NO bioavailability in hypertension. ${ }^{34}$ Further studies demonstrated that, at least partly, this reduction in NO activity is compensated by release of endothelium-derived hyperpolarizing factors. ${ }^{34}$ Infusion of vitamin $C$, that quenches free radicals when infused intraarterially, restored the reduced endothelium-dependent vasodilation in hypertensives, indicating the contribution of OS to the reduced NO bioavailability in hypertension. ${ }^{35}$

Endothelin-1, a powerful endogenous, endotheliumderived vasoconstrictor peptide, is continuously released from the vascular endothelium and contributes to tonic vasomotor constrictor tone. The NO may inhibit the synthesis and hemodynamic effects of ET-1; ET-I can stimulate NO production by stimulating the endothelial ET(B) receptors. ${ }^{36}$ Blockade of ET-1 receptors, either ET(A/B) or ETA, resulted in a significant increase in forearm blood flow in hypertensive, but not in normotensive controls. Moreover, ET blockade also improved acetylcholinemediated responses in hypertensive patients, indicating that increased ET-1 activity may play a role in the pathophysiology of hypertension. ${ }^{37}$ This increased ET-1 activity was shown to be particularly higher in hypertensive black participants compared with white subjects. ${ }^{38}$

\section{ENDOTHELIAL DYSFUNCTION AS A PRECURSOR TO HYPERTENSION}

There is increasing evidence that ED, when present among normotensive subjects, may lead to future development of hypertension. ${ }^{6}$ For example, eNOS knockout mice typically develop hypertension, ${ }^{6}$ infusion of $\mathrm{NO}$ synthase antagonists leads to elevation of blood pressure, ${ }^{39}$ hypertensive subjects appear to have more NOS-3 gene mutations, ${ }^{40}$ and normotensive offspring of hypertensive patients demonstrate impaired endothelial function. ${ }^{41}$ In 952 postmenopausal women, free of risk factors including hypertension, Rossi et $\mathrm{al}^{25}$ found that the incidence of hypertension over a 3.6-year follow-up period was 5.77-fold higher in those in the lowest FMD quartile compared with the highest, indicating a role for ED as a precursor in the development of hypertension. ${ }^{42}$ In MESA, 1869 patients without hypertension were followed over a median of 4.8 years for incident hypertension. While the association between low FMD and incident hypertension was significant, this did not withstand multivariate adjustment for important confounders. ${ }^{43}$

\section{BIOMARKERS OF ENDOTHELIAL DYSFUNCTION}

Endothelial function can be estimated indirectly with certain circulating biomarkers, including ADMA, oxidized low-density lipoprotein, aminothiols including glutathione and cystine, certain adhesion molecules, such as intercellular adhesion molecule-1, endothelial microparticles (EMPs), EPCs, endothelial glycocalyx, monocyte-platelet aggregates, and others.

\section{Asymmetric Dimethylarginine}

Asymmetric dimethylarginine is an endogenous competitive antagonist of NO synthase. ${ }^{44}$ Hypertensive patients have higher ADMA levels compared with normotensive, healthy controls ${ }^{45}$ and higher ADMA levels have been associated with both ED and increased intima-media thickness (IMT). ${ }^{46}$ The ADMA levels correlate with pulse wave velocity, further indicating its contribution to hypertension and increased arterial stiffness. ${ }^{47}$ The ADMA levels are also elevated in those with a high-risk factor burden, chronic kidney disease, ${ }^{48}$ coronary heart disease, and stroke. Importantly, higher ADMA levels are associated with adverse long-term outcomes. ${ }^{49,50}$

\section{Aminothiols}

Oxidative stress is implicated in the pathophysiology of ED as described earlier and in multiple conditions including CVD. ${ }^{50}$ Recent studies have shown the importance of nonfree radical species as indicators and mediators of OS. ${ }^{51}$ Proteins are susceptible to oxidation through alterations of reactive aminothiol residues and such covalent modifications serve to alter their cellular signaling activity, thereby coupling redox modifications of aminothiols to functional activity. ${ }^{52}$ Importantly, these aminothiols can be quantified in plasma to assess the oxidant burden in vivo. ${ }^{53}$ Of these, cysteine constitutes the major aminothiol pool extracellularly that reacts readily with oxidants to form its oxidized disulfide cystine. Intracellularly, glutathione is a major antioxidant that helps eliminate peroxides and maintain cellular redox, and its oxidized form is glutathione disulfide. ${ }^{54}$ We have shown that increased OS, measured as higher levels of cystine, lower levels of glutathione, or altered ratios of oxidized to reduced aminothiols, is associated with cellular dysfunction, aging, risk factors for CVD including hypertension and subclinical vascular disease including ED, microvascular dysfunction, arterial stiffness, increased carotid IMT, and pulmonary hypertension. ${ }^{52,55-62}$

\section{Endothelial Progenitor Cells}

Endothelial progenitor cells are bone marrow-derived stem cells with the potential to differentiate into mature vascular endothelium. Endothelial dysfunction may be considered to be a result of a balance between the magnitude of injury due to exposure to risk factors and the capacity for endothelial repair. ${ }^{63}$ Although risk factor-mediated injury to the 
vascular endothelium is well understood, the mechanisms underlying regeneration and the pivotal role of progenitor cells (PCs) in vascular repair and hence, to cardiovascular health have only recently been appreciated. ${ }^{63-65}$ The EPCs are mononuclear cells that originate primarily (but not exclusively) from the bone marrow and differentiate into endothelial cells both in vitro and in vivo. ${ }^{66,67}$ The PCs reside primarily in bone marrow, circulate, and contribute to blood vessel formation during tissue repair. ${ }^{67-79}$ Endogenous PCs contribute to reendothelialization of tissues after endothelial injury, attenuating progression to frank atherosclerosis. ${ }^{80-85}$ Circulating PCs are multilineage, but the most common circulating PCs are of hematopoietic and EPCs that are capable of vascular repair, largely by their paracrine activities. ${ }^{86,87}$ Our recent studies have shown reduction in the number and migratory activity of PCs in patients with coronary artery disease (CAD) compared with healthy subjects. ${ }^{88-93}$ Endothelial dysfunction correlates with PC number and function. ${ }^{89,94}$ Importantly, a low PC count appears to be an independent predictor of poor outcome in patients with $\mathrm{CAD}_{1}^{89,95}$ stroke, or acute lung injury. ${ }^{94-97}$

\section{Endothelial Microparticles}

Endothelial microparticles are composed of endothelial cellular debris that breaks off into small membrane vesicles comprised of their native cell membrane and cytoplasm. Using flow cytometry, these microparticles are classified into EMPs, leukocyte microparticles, and platelet microparticles (PMPs). ${ }^{98}$ The EMPs have been used as surrogates for $\mathrm{ED}^{99}$ and been associated with decreased NO bioavailability and with the severity of hypertension. ${ }^{100-104}$ In 844 participants enrolled in the Framingham offspring cohort, ${ }^{99}$ circulating EMP levels were associated with the development of traditional cardiovascular risk factors, including hypertension. ${ }^{99}$ Patients with severe hypertension, compared with those with mild hypertension or normal blood pressure, had significantly elevated EMPs and PMPs. ${ }^{103}$

\section{Therapeutic Targets}

Both classic antihypertensive therapies, therapy targeted toward cardiovascular risk factors and therapy targeting the NO pathway, have been studied in patients with hypertension. ${ }^{105}$ Antihypertensive agents, including angiotensin-converting enzyme inhibitors (ACEi), angiotensin-II type I receptor blockers (ARBs), nebivolol, a third-generation beta receptor antagonist, and amlodipine, appear to improve ED in patients with hypertension. ${ }^{106-108}$ In a meta-analysis involving 1,129 heterogeneous patients at increased cardiovascular risk, ACEi and ARBs significantly improved brachial
FMD compared with beta-blockers and calcium channel blockers. ${ }^{108}$ Both irbesartan and nebivolol in combination with hydrochlorothiazide improved vascular function in hypertension. ${ }^{107}$ Nebivolol, in particular, has demonstrated increased NO availability, enhanced antithrombotic activity, and improvement in markers of ED. ${ }^{107}$ Both in patients with essential hypertension and in murine models, the combination of amlodipine and atorvastatin improved vascular function. ${ }^{109}$ The $\mathrm{BH} 4$ acts as a cofactor of NO synthase and a scavenger for free radicals. ${ }^{110} \mathrm{In}$ patients with hypertension receiving $\mathrm{BH} 4$ supplementation, investigators have demonstrated improvement in endothelial function. ${ }^{110}$

\section{SUMMARY}

Hypertension is characterized by ED, reduced NO bioavailability, and increased OS, and ED may even precede the development of hypertension. The magnitude of ED is predictive of adverse cardiovascular outcomes, and improvement in ED by medications and other means may reflect reduced risk. Markers that reflect ED are being studied for utility, validity, and clinical application.

\section{REFERENCES}

1. Gkaliagkousi E, Gavriilaki E, Triantafyllou A, Douma S. Clinical significance of endothelial dysfunction in essential hypertension. Curr Hypertens Rep 2015 Nov;17(11):85.

2. Konukoglu D, Uzun H. Endothelial dysfunction and hypertension. Adv Exp Med Biol 2017;956:511-540.

3. Vane JR, Anggard EE, Botting RM. Regulatory functions of the vascular endothelium. N Engl J Med 1990 Jul;323(1):27-36.

4. Panza JA, Quyyumi AA, Brush JE Jr, Epstein SE. Abnormal endothelium-dependent vascular relaxation in patients with essential hypertension. N Engl J Med 1990 Jul;323(1):22-27.

5. Quyyumi AA, Dakak N, Mulcahy D, Andrews NP, Husain S, Panza JA, Cannon RO 3rd. Nitric oxide activity in the atherosclerotic human coronary circulation. J Am Coll Cardiol 1997 Feb;29(2):308-317.

6. Quyyumi AA, Patel RS. Endothelial dysfunction and hypertension: cause or effect? Hypertension 2010 May; 55(5): 1092-1094.

7. Dudzinski DM, Igarashi J, Greif D, Michel T. The regulation and pharmacology of endothelial nitric oxide synthase. Annu Rev Pharmacol Toxicol 2006;46:235-276.

8. Aicher A, Heeschen C, Mildner-Rihm C, Urbich C, Ihling C, Technau-Ihling K, Zeiher AM, Dimmeler S. Essential role of endothelial nitric oxide synthase for mobilization of stem and progenitor cells. Nat Med 2003 Nov;9(11):1370-1376.

9. Quyyumi AA, Dakak N, Andrews NP, Husain S, Arora S, Gilligan DM, Panza JA, Cannon RO 3rd. Nitric oxide activity in the human coronary circulation. Impact of risk factors for coronary atherosclerosis. J Clin Invest 1995 Apr;95(4): 1747-1755.

10. Quyyumi AA, Dakak N, Andrews NP, Gilligan DM, Panza JA, Cannon RO 3rd. Contribution of nitric oxide to metabolic coronary vasodilation in the human heart. Circulation 1995 Aug;92(3):320-326. 
11. Linder L, Kiowski W, Buhler FR, Luscher TF. Indirect evidence for release of endothelium-derived relaxing factor in human forearm circulation in vivo. Blunted response in essential hypertension. Circulation 1990 Jun;81(6):1762-1767.

12. Panza JA, Garcia CE, Kilcoyne CM, Quyyumi AA, Cannon RO 3rd. Impaired endothelium-dependent vasodilation in patients with essential hypertension. Evidence that nitric oxide abnormality is not localized to a single signal transduction pathway. Circulation 1995 Mar;91(6):1732-1738.

13. Gilligan DM, Guetta V, Panza JA, Garcia CE, Quyyumi AA, Cannon RO 3rd. Selective loss of microvascular endothelial function in human hypercholesterolemia. Circulation 1994 Jul;90(1):35-41.

14. Gilligan DM, Badar DM, Panza JA, Quyyumi AA, Cannon RO3rd. Effects of estrogen replacement therapy on peripheral vasomotor function in postmenopausal women. Am J Cardiol 1995 Feb;75(4):264-268.

15. Garcia CE, Kilcoyne CM, Cardillo C, Cannon RO 3rd, Quyyumi AA, Panza JA. Evidence that endothelial dysfunction in patients with hypercholesterolemia is not due to increased extracellular nitric oxide breakdown by superoxide anions. Am J Cardiol 1995 Dec;76(16):1157-1161.

16. Cardillo C, Kilcoyne CM, Quyyumi AA, Cannon RO 3rd, Panza JA. Selective defect in nitric oxide synthesis may explain the impaired endothelium-dependent vasodilation in patients with essential hypertension. Circulation 1998 Mar;97(9):851-856

17. Cardillo C, Kilcoyne CM, Quyyumi AA, Cannon RO 3rd, Panza JA. Decreased vasodilator response to isoproterenol during nitric oxide inhibition in humans. Hypertension 1997 Oct;30(4):918-921.

18. Cardillo C, Kilcoyne CM, Quyyumi AA, Cannon RO 3rd, Panza JA. Role of nitric oxide in the vasodilator response to mental stress in normal subjects. Am J Cardiol 1997 Oct; $80(8): 1070-1074$.

19. Cardillo C, Kilcoyne CM, Quyyumi AA, Cannon RO 3rd, Panza JA. Increased activity of endogenous endothelin in hypercholesterolemic patients. Circulation 1997;96(8): 1395-1395.

20. Cardillo C, Kilcoyne CM, Cannon RO 3rd, Quyyumi AA, Panza JA. Xanthine oxidase inhibition with oxypurinol improves endothelial vasodilator function in hypercholesterolemic but not in hypertensive patients. Hypertension 1997 Jul;30(1 Pt 1):57-63.

21. Anderson TJ, Uehata A, Gerhard MD, Meredith IT, Knab S, Delagrange D, Lieberman EH, Ganz P, Creager MA, Yeung AC, et al. Close relation of endothelial function in the human coronary and peripheral circulations. J Am Coll Cardiol 1995 Nov;26(5):1235-1241.

22. Matsuzawa $Y$, Kwon TG, Lennon RJ, Lerman LO, Lerman A. Prognostic value of flow-mediated vasodilation in brachial artery and fingertip artery for cardiovascular events: a systematic review and meta-analysis. J Am Heart Assoc 2015 Nov;4(11):e002270.

23. Xu Y, Arora RC, Hiebert BM, Lerner B, Szwajcer A, McDonald K, Rigatto C, Komenda P, Sood MM, Tangri N. Non-invasive endothelial function testing and the risk of adverse outcomes: a systematic review and meta-analysis. Eur Heart J Cardiovasc Imaging 2014 Jul;15(7):736-746.

24. Yeboah J, Folsom AR, Burke GL, Johnson C, Polak JF, Post W, Lima JA, Crouse JR, Herrington DM. Predictive value of brachial flow-mediated dilation for incident cardiovascular events in a population-based study: the multi-ethnic study of atherosclerosis. Circulation 2009 Aug;120(6):502-509.

25. Rossi R, Nuzzo A, Origliani G, Modena MG. Prognostic role of flow-mediated dilation and cardiac risk factors in postmenopausal women. J Am Coll Cardiol 2008 Mar;51(10): 997-1002.

26. Yeboah J, Crouse JR, Hsu FC, Burke GL, Herrington DM. Brachial flow-mediated dilation predicts incident cardiovascular events in older adults: the Cardiovascular Health Study. Circulation 2007 May;115(18):2390-2397.

27. Matsuzawa Y, Li J, Aoki T, Guddeti RR, Kwon TG, Cilluffo R, Widmer RJ, Gulati R, Lennon RJ, Lerman LO, et al. Predictive value of endothelial function by noninvasive peripheral arterial tonometry for coronary artery disease. Coron Artery Dis 2015 May;26(3):231-238.

28. Paniagua OA, Bryant MB, Panza JA. Transient hypertension directly impairs endothelium-dependent vasodilation of the human microvasculature. Hypertension 2000 Dec;36(6): 941-944.

29. Juonala M, Viikari JS, Rönnemaa T, Helenius H, Taittonen L, Raitakari OT. Elevated blood pressure in adolescent boys predicts endothelial dysfunction: the cardiovascular risk in young Finns study. Hypertension 2006 Sep;48(3):424-430.

30. Dohi Y, Thiel MA, Buhler FR, Luscher TF. Activation of endothelial L-arginine pathway in resistance arteries. Effect of age and hypertension. Hypertension 1990 Aug;16(2): 170-179.

31. Hermann M, Flammer A, Luscher TF. Nitric oxide in hypertension. J Clin Hypertens (Greenwich) 2006 Dec;8(12 Suppl 4):17-29.

32. Shimbo D, Muntner P, Mann D, Viera AJ, Homma S, Polak JF, Barr RG, Herrington D, Shea S. Endothelial dysfunction and the risk of hypertension: the multi-ethnic study of atherosclerosis. Hypertension 2010 May;55(5):1210-1216.

33. Cockcroft JR, Chowienczyk PJ, Benjamin N, Ritter JM. Preserved endothelium-dependent vasodilatation in patients with essential hypertension. N Engl J Med 1994 Apr;330(15):1036-1040.

34. Panza JA, Casino PR, Kilcoyne CM, Quyyumi AA. Role of endothelium-derived nitric oxide in the abnormal endothelium-dependent vascular relaxation of patients with essential hypertension. Circulation 1993 May;87(5):1468-1474.

35. Ozkor, M.; Murrow, J.;Kavtaradze, N.; Sheikh, A.; Jorgensen, J.; Pohel, K.; Manatunga, A.; Quyyumi, A. The contribution of endothelial-derived hyperpolarising factor and nitric oxide to basal and stimulatory vasodilator tone in metabolic syndrome. Paper presented at: Annual Scientific Conference of the British-Cardiovascular-Society; Jun 02-04, 2008. Manchester, England.

36. Cardillo C, Kilcoyne CM, Cannon RO 3rd, Panza JA. Interactions between nitric oxide and endothelin in the regulation of vascular tone of human resistance vessels in vivo. Hypertension 2000 Jun;35(6):1237-1241.

37. Cardillo C, Campia U, Kilcoyne CM, Bryant MB, Panza JA. Improved endothelium-dependent vasodilation after blockade of endothelin receptors in patients with essential hypertension. Circulation 2002 Jan;105(4):452-456.

38. Campia U, Cardillo C, Panza JA. Ethnic differences in the vasoconstrictor activity of endogenous endothelin-1 in hypertensive patients. Circulation 2004 Jun;109(25):3191-3195.

39. Gkaliagkousi E, Douma S, Zamboulis C, Ferro A. Nitric oxide dysfunction in vascular endothelium and platelets: 
role in essential hypertension. J Hypertens 2009 Dec;27(12): 2310-2320.

40. Sander M, Chavoshan B, Victor RG. A large blood pressureraising effect of nitric oxide synthase inhibition in humans. Hypertension 1999 Apr;33(4):937-942.

41. Hyndman ME, Parsons HG, Verma S, Bridge PJ, Edworthy S, Jones C, Lonn E, Charbonneau F, Anderson TJ. The T-786-->C mutation in endothelial nitric oxide synthase is associated with hypertension. Hypertension 2002 Apr;39(4):919-922.

42. Taddei S, Virdis A, Mattei P, Ghiadoni L, Sudano I, Salvetti $A$. Defective L-arginine-nitric oxide pathway in offspring of essential hypertensive patients. Circulation 1996 Sep;94(6):1298-1303.

43. Shimbo D, Muntner P, Mann D, Viera AJ, Homma S, Polak JF, Barr RG, Herrington D, Shea S. Endothelial dysfunction and the risk of hypertension: the multi-ethnic study of atherosclerosis. Hypertension 2010 May;55(5):1210-1216.

44. Smith SC Jr, Anderson JL, Cannon RO 3rd, Fadl YY, Koenig W, Libby P, Lipshultz SE, Mensah GA, Ridker PM, Rosenson R, et al. CDC/AHA workshop on markers of inflammation and cardiovascular disease: application to clinical and public health practice: report from the clinical practice discussion group. Circulation 2004 Dec;110(25):e550-e553.

45. PerticoneF, Sciacqua A, Maio R, Perticone M, Maas R, Boger RH, Tripepi G, Sesti G, Zoccali C. Asymmetric dimethylarginine, L-arginine, and endothelial dysfunction in essential hypertension. J Am Coll Cardiol 2005 Aug;46(3):518-523.

46. Serg M, Kampus P, Kals J, Zagura M, Muda P, Tuomainen TP, Zilmer K, Salum E, Zilmer M, Eha J. Association between asymmetric dimethylarginine and indices of vascular function in patients with essential hypertension. Blood Press 2011 Apr;20(2):111-116.

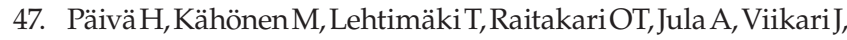
Alfthan G, Juonala M, Laaksonen R, Hutri-Kähönen N. Asymmetric dimethylarginine (ADMA) has a role in regulating systemic vascular tone in young healthy subjects: the cardiovascular risk in young Finns study. Am J Hypertens 2008 Aug;21(8):873-878.

48. Langsford D, Tang M, Cheikh Hassan HI, Djurdjev O, Sood MM, Levin A. The association between biomarker profiles, etiology of chronic kidney disease, and mortality. Am J Nephrol 2017 Feb;45(3):226-234.

49. Willeit P, Freitag DF, Laukkanen JA, Chowdhury S, Gobin R, Mayr M, Di Angelantonio E, Chowdhury R. Asymmetric dimethylarginine and cardiovascular risk: systematic review and meta-analysis of 22 prospective studies. J Am Heart Assoc 2015 May;4(6):e001833.

50. Xuan C, Tian QW, Li H, Zhang BB, He GW, Lun LM. Levels of asymmetric dimethylarginine (ADMA), an endogenous nitric oxide synthase inhibitor, and risk of coronary artery disease: a meta-analysis based on 4713 participants. Eur J Prev Cardiol 2016 Mar;23(5):502-510.

51. Harrison D, Griendling KK, Landmesser U,Hornig B, DrexlerH. Role of oxidative stress in atherosclerosis. Am J Cardiol 2003 Feb;91(3A):7A-11A.

52. Jones DP. Radical-free biology of oxidative stress. Am J Physiol Cell Physiol 2008 Oct;295(4):C849-C868.

53. Go YM, Jones DP. Thiol/disulfide redox states in signaling and sensing. Crit Rev Biochem Mol Biol 2013 MarApr;48(2):173-181.

54. Jones DP, Liang Y. Measuring the poise of thiol/disulfide couples in vivo. Free Radic Biol Med 2009 Nov;47(10): 1329-1338.
55. Ashfaq S, Abramson JL, Jones DP, Rhodes SD, Weintraub WS, Hooper WC, Vaccarino V, Harrison DG, Quyyumi AA. The relationship between plasma levels of oxidized and reduced thiols and early atherosclerosis in healthy adults. J Am Coll Cardiol 2006 Mar;47(5):1005-1011.

56. Patel RS, Al Mheid I, Morris AA, Ahmed Y, Kavtaradze N, Ali S, Dabhadkar K, Brigham K, Hooper WC, Alexander RW, et al. Oxidative stress is associated with impaired arterial elasticity. Atherosclerosis 2011 Sep;218(1):90-95.

57. Go YM, Jones DP. Intracellular proatherogenic events and cell adhesion modulated by extracellular thiol/disulfide redox state. Circulation 2005 Jun;111(22):2973-2980.

58. Nkabyo YS, Ziegler TR, Gu LH, Watson WH, Jones DP. Glutathione and thioredoxin redox during differentiation in human colon epithelial (Caco-2) cells. Am J Physiol Gastrointest Liver Physiol 2002 Dec;283(6):G1352-G1359.

59. Dröge W. The plasma redox state and ageing. Ageing Res Rev 2002 Apr;1(2):257-278.

60. Samiec PS, Drews-Botsch C, Flagg EW, Kurtz JC, Sternberg P Jr, Reed RL, Jones DP. Glutathione in human plasma: decline in association with aging, age-related macular degeneration, and diabetes. Free Radic Biol Med 1998 Mar;24(5):699-704.

61. Ashfaq S, Beinart SC, Abramson JL, Rhodes SD, Jurkovitz C, Vaccarino V, Williams JK, Jones DP, Quyyumi AA, Weintraub WS, Harrison DG. Plasma glutathione redox state: a novel marker of oxidative stress, correlates with early atherosclerosis in humans. J Am Coll Cardiol 2003;41(Suppl A):293A-294A.

62. Ghasemzadeh N, Patel RS, Eapen DJ, Veledar E, Al Kassem H, Manocha P, Khayata M, Zafari AM, Sperling L, Jones DP, et al. Oxidative stress is associated with increased pulmonary artery systolic pressure in humans. Hypertension 2014 Jun;63(6):1270-1275.

63. Hill JM, Zalos G, Halcox JP, Schenke WH, Waclawiw MA, Quyyumi AA, Finkel T. Circulating endothelial progenitor cells, vascular function, and cardiovascular risk. N Engl J Med 2003 Feb;348(7):593-600.

64. Asahara T, Murohara T, Sullivan A, Silver M, van der Zee R, Li T, Witzenbichler B, Schatteman G, Isner JM. Isolation of putative progenitor endothelial cells for angiogenesis. Science 1997 Feb;275(5302):964-967.

65. Lin Y, Weisdorf DJ, Solovey A, Hebbel RP. Origins of circulating endothelial cells and endothelial outgrowth from blood. J Clin Invest 2000 Jan;105(1):71-77.

66. Quyyumi AA. Endothelial function in health and disease: new insights into the genesis of cardiovascular disease. Am J Med 1998 Jul;105(1A):32S-39S.

67. Urbich C, Dimmeler S. Endothelial progenitor cells: characterization and role in vascular biology. Circ Res 2004 Aug;95(4):343-353.

68. Urbich C, Dimmeler S. Endothelial progenitor cells functional characterization. Trends Cardiovasc Med 2004 Nov;14(8): 318-322.

69. Springer ML, Chen AS, Kraft PE, Bednarski M, Blau HM. VEGF gene delivery to muscle: potential role for vasculogenesis in adults. Mol Cell 1998 Nov;2(5):549-558.

70. Asahara T, Kalka C, Isner JM. Stem cell therapy and gene transfer for regeneration. Gene Ther 2000 Mar;7(6):451-457.

71. Murohara T, Ikeda H, Duan J, Shintani S, Sasaki Ki, Eguchi H, Onitsuka I, Matsui K, Imaizumi T. Transplanted cord blood-derived endothelial precursor cells augment postnatal neovascularization. J Clin Invest 2000 Jun;105(11): 1527-1536. 
72. Urbich C, Heeschen C, Aicher A, Dernbach E, Zeiher AM, Dimmeler S. Relevance of monocytic features for neovascularization capacity of circulating endothelial progenitor cells. Circulation 2003 Nov;108(20):2511-2516.

73. Takahashi T, Kalka C, Masuda H, Chen D, Silver M, Kearney M, Magner M, Isner JM, Asahara T. Ischemia- and cytokineinduced mobilization of bone marrow-derived endothelial progenitor cells for neovascularization. Nat Med 1999 Apr;5(4): 434-438.

74. Risau W. Mechanisms of angiogenesis. Nature 1997 Apr;386(6626):671-674.

75. Schaper W, Scholz D. Factors regulating arteriogenesis. Arterioscler Thromb Vasc Biol 2003 Jul;23(7):1143-1151.

76. Subramaniyam V, Reddy U, Sutcliffe D, Harris W, LeFever S, Waller E, Taylor WR, Kolm P, Alexander W, Quyyumi AA. Stimulation of endothelial progenitor cells with granulocytemacrophage colony stimulating factor improves endothelial dysfunction in patients with peripheral arterial disease. J Am Coll Cardiol 2006 Feb;47(4):A381-A384.

77. Crosby JR, Kaminski WE, Schatteman G, Martin PJ, Raines EW, Seifert RA, Bowen-Pope DF. Endothelial cells of hematopoietic origin make a significant contribution to adult blood vessel formation. Circ Res 2000 Oct;87(9):728-730.

78. Jackson KA, Majka SM, Wang H, Pocius J, Hartley CJ, Majesky MW, Entman ML, Michael LH, Hirschi KK, Goodell MA. Regeneration of ischemic cardiac muscle and vascular endothelium by adult stem cells. J Clin Invest 2001 Jun;107(11):1395-1402.

79. Kocher AA, Schuster MD, Szabolcs MJ, Takuma S, Burkhoff D, Wang J, Homma S, Edwards NM, Itescu S. Neovascularization of ischemic myocardium by human bone-marrowderived angioblasts prevents cardiomyocyte apoptosis, reduces remodeling and improves cardiac function. Nat Med 2001 Apr;7(4):430-436.

80. Murayama T,TepperOM,Silver M,MaH,LosordoDW,IsnerJM, Asahara T, Kalka C. Determination of bone marrow-derived endothelial progenitor cell significance in angiogenic growth factor-induced neovascularization in vivo. Exp Hematol 2002 Aug;30(8):967-972.

81. Peichev M, Naiyer AJ, Pereira D, Zhu Z, Lane WJ, Williams M, Oz MC, Hicklin DJ, Witte L, Moore MA, et al. Expression of VEGFR-2 and AC133 by circulating human CD34+ cells identifies a population of functional endothelial precursors. Blood 2000 Feb;95(3):952-958.

82. Fujiyama S, Amano K, Uehira K, Yoshida M, Nishiwaki Y, Nozawa Y, Jin D, Takai S, Miyazaki M, Egashira K, et al. Bone marrow monocyte lineage cells adhere on injured endothelium in a monocyte chemoattractant protein-1-dependent manner and accelerate reendothelialization as endothelial progenitor cells. Circ Res 2003 Nov;93(10):980-989.

83. Griese DP, Ehsan A, Melo LG, Kong D, Zhang L, Mann MJ, Pratt RE, Mulligan RC, Dzau VJ. Isolation and transplantation of autologous circulating endothelial cells into denuded vessels and prosthetic grafts: implications for cell-based vascular therapy. Circulation 2003 Nov;108(21):2710-2715.

84. Werner N, Priller J, Laufs U, Endres M, Böhm M, Dirnagl U, Nickenig G. Bone marrow-derived progenitor cells modulate vascular reendothelialization and neointimal formation: effect of 3-hydroxy-3-methylglutaryl coenzyme a reductase inhibition. Arterioscler Thromb Vasc Biol 2002 Oct;22(10):1567-1572.
85. Rauscher FM, Goldschmidt-Clermont PJ, Davis BH, Wang T, Gregg D, Ramaswami P, Pippen AM, Annex BH, Dong C, Taylor DA. Aging, progenitor cell exhaustion, and atherosclerosis. Circulation 2003 Jul;108(4):457-463.

86. Gunsilius E, Duba H-C, Petzer AL, Kähler CM, Grünewald K, Stockhammer G, Gabl C, Dirnhofer S, Clausen J, Gastl G. Evidence from a leukaemia model for maintenance of vascular endothelium by bone-marrow-derived endothelial cells. Lancet 2000 May;355(9216):1688-1691.

87. $\mathrm{Xu} \mathrm{S,} \mathrm{Zhu} \mathrm{J,} \mathrm{Yu} \mathrm{L,} \mathrm{Fu} \mathrm{G.} \mathrm{Endothelial} \mathrm{progenitor} \mathrm{cells:} \mathrm{current}$ development of their paracrine factors in cardiovascular therapy. J Cardiovasc Pharmacol 2012 Apr;59(4):387-396.

88. Shimada IS, Spees JL. Stem and progenitor cells for neurological repair: minor issues, major hurdles, and exciting opportunities for paracrine-based therapeutics. J Cell Biochem 2011 Feb;112(2):374-380.

89. Heiss C, Keymel S, Niesler U, Ziemann J, Kelm M, Kalka C. Impaired progenitor cell activity in age-related endothelial dysfunction. J Am Coll Cardiol 2005 May;45(9):1441-1448.

90. Scheubel RJ, Zorn H, Silber RE, Kuss O, Morawietz H, Holtz J, Simm A. Age-dependent depression in circulating endothelial progenitor cells in patients undergoing coronary artery bypass grafting. J Am Coll Cardiol 2003 Dec;42(12):2073-2080.

91. Vasa M, Fichtlscherer S, Adler K, Aicher A, Martin H, Zeiher AM, Dimmeler S. Increase in circulating endothelial progenitor cells by statin therapy in patients with stable coronary artery disease. Circulation 2001 Jun;103(24):2885-2890.

92. Britten MB, Abolmaali ND, Assmus B, Lehmann R, Honold J, Schmitt J, Vogl TJ, Martin H, Schächinger V, Dimmeler S, et al. Infarct remodeling after intracoronary progenitor cell treatment in patients with acute myocardial infarction (TOPCARE-AMI): mechanistic insights from serial contrastenhanced magnetic resonance imaging. Circulation 2003 Nov;108(18):2212-2218.

93. Tepper OM, Galiano RD, Capla JM, Kalka C, Gagne PJ, Jacobowitz GR, Levine JP, Gurtner GC. Human endothelial progenitor cells from type II diabetics exhibit impaired proliferation, adhesion, and incorporation into vascular structures. Circulation 2002 Nov;106(22):2781-2786.

94. Ghani U, Shuaib A, Salam A, Nasir A, Shuaib U, Jeerakathil T, Sher F, O'Rourke F, Nasser AM, Schwindt B, et al. Endothelial progenitor cells during cerebrovascular disease. Stroke 2005 Jan;36(1):151-153.

95. Schmidt-Lucke C, Rossig L, Fichtlscherer S, Vasa M, Britten M, Kämper U, Dimmeler S, Zeiher AM. Reduced number of circulating endothelial progenitor cells predicts future cardiovascular events: proof of concept for the clinical importance of endogenous vascular repair. Circulation 2005 Jun;111(22):2981-2987.

96. Werner N, Kosiol S, Schiegl T, Ahlers P, Walenta K, Link A, Böhm M, Nickenig G. Circulating endothelial progenitor cells and cardiovascular outcomes. N Engl J Med 2005 Sep;353(10):999-1007.

97. Fadini GP, de Kreutzenberg S, Agostini C, Boscaro E, Tiengo A, Dimmeler S, Avogaro A. Low CD34+ cell count and metabolic syndrome synergistically increase the risk of adverse outcomes. Atherosclerosis 2009 Nov;207(1):213-219.

98. Wolf $\mathrm{P}$. The nature and significance of platelet products in human plasma. Br J Haematol 1967 May;13(3):269-288.

99. Amabile N, Cheng S, Renard JM, Larson MG, Ghorbani A, McCabe E, Griffin G, Guerin C, Ho JE, Shaw SY, et al. Association of circulating endothelial microparticles with 
cardiometabolic risk factors in the Framingham Heart Study. Eur Heart J 2014 Nov;35(42):2972-2979.

100. Helbing T, Olivier C, Bode C, Moser M, Diehl P. Role of microparticles in endothelial dysfunction and arterial hypertension. World J Cardiol 2014 Nov;6(11):1135-1139.

101. Burger D, Montezano AC, Nishigaki N, He Y, Carter A, Touyz RM. Endothelial microparticle formation by angiotensin II is mediated via Ang II receptor type I/NADPH oxidase/ Rho kinase pathways targeted to lipid rafts. Arterioscler Thromb Vasc Biol 2011 Aug;31(8):1898-1907.

102. Boulanger CM, Scoazec A, Ebrahimian T, Henry P, Mathieu E, Tedgui A, Mallat Z. Circulating microparticles from patients with myocardial infarction cause endothelial dysfunction. Circulation 2001 Nov;104(22):2649-2652.

103. Preston RA, Jy W, Jimenez JJ, Mauro LM, Horstman LL, Valle M, Aime G, Ahn YS. Effects of severe hypertension on endothelial and platelet microparticles. Hypertension 2003 Feb;41(2):211-217.

104. Wang JM, Yang Z, Xu MG, Chen L, Wang Y, Su C, Tao J. Berberine-induced decline in circulating CD31+/CD42microparticles is associated with improvement of endothelial function in humans. Eur J Pharmacol 2009 Jul;614(1-3): 77-83.

105. Flammer AJ, Anderson T, Celermajer DS, Creager MA, Deanfield J, Ganz P, Hamburg NM, Lüscher TF, Shechter M, TaddeiS, et al. The assessment of endothelial function: from research into clinical practice. Circulation 2012 Aug;126(6):753-767.

106. Suzuki R, Fukuda N, Katakawa M, Tsunemi A, Tahira Y, Matsumoto T, Ueno T, Soma M. Effects of an angiotensin II receptor blocker on the impaired function of endothelial progenitor cells in patients with essential hypertension. Am J Hypertens 2014 May;27(5):695-701.

107. Vitale C, Marazzi G, Iellamo F, Spoletini I, Dall'Armi V, Fini M, Volterrani M. Effects of nebivolol or irbesartan in combination with hydrochlorothiazide on vascular functions in newlydiagnosed hypertensive patients: the NINFE (Nebivololo, Irbesartan Nella Funzione Endoteliale) study. Int J Cardiol 2012 Mar;155(2):279-284.

108. Shahin Y, Khan JA, Samuel N, Chetter I. Angiotensin converting enzyme inhibitors effect on endothelial dysfunction: a meta-analysis of randomised controlled trials. Atherosclerosis 2011 May;216(1):7-16.

109. He Y, Si D, Yang C, Ni L, Li B, Ding M, Yang P. The effects of amlodipine and $\mathrm{S}(-)$-amlodipine on vascular endothelial function in patients with hypertension. Am J Hypertens 2014 Jan;27(1):27-31.

110. Porkert M, Sher S, Reddy U, Cheema F, Niessner C, Kolm P, Jones DP, Hooper C, Taylor WR, Harrison D, et al. Tetrahydrobiopterin: a novel antihypertensive therapy. J Hum Hypertens 2008 Jun;22(6):401-407. 